\title{
BREEDING POTENTIALITIES OF SHORT SEASON Barbadense COTTONS THROUGH LATE PLANTING
}

\author{
(Received : 8.12. 2014)
}

\author{
By \\ A. M. A. Abdalla \\ Agronomy Department, Faculty of Agriculture, Cairo university, Giza, Egypt
}

\begin{abstract}
The main objective of the current investigation was to introduce a rapid genetic assay for testing cotton (G. barbadense) genotypes to endure the late planting conditions. A set of properly selected nine divergent lines was crossed in a 5X4 Factorial-mating design II fashion. Parental lines and their $20 \mathrm{~F}_{2}$ crosses were evaluated for growth-based and yield-based earliness traits in two divergent planting dates (Middle march, $\mathrm{D}_{1}$, and Middle May, $\mathrm{D}_{2}$ ) at Cairo University Experimental Station in the summer seasons of 2010 through 2012. The parental genotypes G90 (cultivar; $\bar{x}=39.70 \mathrm{~g} / \mathrm{plant}$, $\overline{\mathrm{S}}=0.49$ ), PS6(Egyptian - American; $\overline{\mathrm{x}}=39.80 \mathrm{~g} /$ plant,$\overline{\mathrm{S}}=0.80$ ) andG75 (obsolete cultivar; $\overline{\mathrm{x}}=$ $39 \mathrm{~g} /$ plant,$\overline{\mathrm{S}}=0.71$ ) were identified as late planting (LP) stress tolerant. They showed a high yield potential in late planting and possessed a low to moderate LP susceptibility index "S". Genotypes G90, EC2, PS6 and PS7 were identified as high earliness index stress tolerant. The "S" values based on seed cotton (SC/P) revealed that the cross combinations G86 x G75 (4), G90x G75 (12), G80 x PS7 (18), and G80 x G83 (19) were moderate LP stress tolerance. These crosses showed the highest yield potential at D2. Cross combinations EC1 x PS6, G90 x PS7, EC2 x PS6, EC2 x G83 and G80 x PS6 were earlier, hence, required less number of days to first boll and recorded the highest earliness index. Significant additive and non-additive variation exhibited in the traits expression. The variances due to general combining ability (GCA) were large in magnitude than those due to specific combining ability (SCA), only for first fruiting node, days to first flower (LP), and days to first boll (LP); the remained traits showed greater variances of SCA. These results were supported by the ratios obtained for the relative importance (RI) of additive to non-additive variances. The average degrees of dominance over all loci indicated partial dominance of various degrees for all studied traits. The broad sense heritability was greater than narrow sense for all traits. This was associated with high narrow sense heretabilities with some traits. The study concluded to the following recommendations: 1) the lines EC1, EC2, PS6 and their descendents can be utilized as a breeding nucleus to develop barbadense genotypes that can be planted up to early May, 2) LP tolerant genotypes should have low "s" index, shorter than current genotypes, having low node of first sympodial, early for days to first boll and have high yielding capacity reflected in high earliness index, 3) breeding by backcrossing with the selected genotypes followed by repeated selfing is a successful breeding strategy for improving tolerance to late planting and enhance shortening the growing season.
\end{abstract}

Key words: combining ability, Egyptian cottons, factorial crossing, genetic parameters, late sowing, stress conditions.

\section{INTRODUCTION}

Recently, there has been an interest among cotton breeders for releasing short-season $G$. barbadense cottons without the aid of shortseason closer relatives of $G$. hirsutum cottons. Interests also extended to provide a reliable plan of management system for delayed planting in order to minimize yield loss associated with late planting and provide a greater flexibility in cropping pattern. These goals achievement depend mainly on the presence of useful genetic variation in the local germplasm or, if necessary, the introduction of new sources of genetic variability from the closer barbadense germplasm that will be tested under altered environments. The golden rule is that cotton production must be profitable for the growers and the fibers must be of the needed quality. The 
adverse conditions of late sowing not only influence cotton yield but also mask genetic improvement in cotton yield and fiber quality (Pettigrew and Meredith, 2009). The awareness of the adverse effect of late sowing on growth, earliness, yield, and quality of cultivated fullseason barbadense cotton derived to consider late sowing as a stress condition. Therefore, the current research was built upon the idea of breeding -by crossing- in the within barbadense germplasm (cultivated, obsolete or introduced) and exploit two divergent sowing dates (conventional; $\mathrm{CN}$ and late planting; LP) for yield and earliness capacity evaluation as well as the mode of gene introgression. The nine parents exploited in the current study included five welladapted Egyptian germplasm, two obsolete Egyptian cottons, and two genotypes introduced from Pima germplasm. Egyptian and Pima are members of long and extra long staple cottons. Hybridization with cottons from Pima germplasm was adopted for many reasons. Pima S7 cotton is more determinant (earlier in nature), improved for heat tolerance, improved for yield capacity, and maintained excellent fiber quality characteristics compared to other barbadense genotypes (Silvertooth, 1994). Cotton previous studies reported two concepts of shortening the growing seasons. First; growing plants in full season, i.e., normal planting date followed by early harvest (Kittock and Taylor, 1985). In such case, breeding efforts emphasized the improvement of earliness traits for shortening growing season. In their analysis of earliness in cotton, Godoy and Palomo (1999) studied twelve morphological, phenological and yield earliness variables. They concluded that the most important variables were node number of first fruiting branch (FFB), days to first boll (DFB), and earliness index (EI). The second concept was shortening cotton growing season through late planting (Porter et al., 1995). In such case, breeding effort should be emphasized on the differential response of barbadense genotypes to be grown under adverse conditions of late planting. Late planting susceptibility index "S" of Fischer and Maurer (1978) was proposed as a complementary approach to the direct evaluation of traits performance under stressed environments. The main advantage of "S" criterion over the per se performance is its independence from genetic effects due to stress conditions by comparing yield performance in the presence and in the absence of the adverse conditions. The " $\mathrm{S}$ " index provides a measure of late stress tolerance based on the minimization of yield loss under stress as compared to optimum conditions (Khanna and Viswana, 1999).

On the other hand, short-season genotypes of Egyptian cottons are important in southern Delta Nile and Upper Egypt cotton zone. This is due to the expected overlapping in growing time when growing cotton with winter crops like wheat, legumes, and canola in double cropping pattern (Abdalla and Abd El-Zaher, 2012). Previous works reported growing cotton in double cropping systems with small grain (Smith and Varvil, 1984) or with winter cover crops in killed strips (Grissco et al., 1984). Percy and Turcotte (1988) addressed several issues associated with the development of shortfibered, short-statured, and early-maturing $G$. barbadense strains. The concept of monoculture of short season cotton after winter wheat was raised in many countries, of them China (Lin et al., 1990), USA (May and Bridges, 1995) and Egypt (Abo El-Zahab, 1994). The limiting factors in successfully producing barbadense cottons in double cropping system are the length of fruiting period and adequate temperature for boll maturation. In recent years, Egyptian cotton researches gave much attention to relay intercropping of cotton on wheat to overcome the problem of time overlapping with the preceding winter crops. Abdalla and Abd ElZaher (2012) reported that relay cropping of cotton on wheat under Egyptian conditions was found to be sustainable i.e., environmental resources (land, fertilizer, and other agroeconomic variables) use efficient compared with regular cropping. Cotton breeders should continue their efforts to characterize the late planting tolerant and earlier genotypes to develop short season and faster maturing genotypes than those under cultivation.

\section{MATERIALS AND METHODS}

\subsection{Genetic materials and experimental procedures}

Field experiments were conducted during 2010 through 2012 crop seasons at Cairo University Experimental Farm, Giza, Egypt. Nine inbred lines of Egyptian cottons (Gossypium barbadense) were used as parents. Seven inbreds [Giza (G) 80, G86, G90, experimental cross (EC1) G84 x (G68 x G74), EC2 (G77 x PS6), G83 and G75)] originally belong to Cotton Research Institute, Ministry of Agriculture, Egypt, and the other two genotypes 
(PS6 and PS7) belong to Pima (EgyptianAmerican) germplasm (Abdalla et al. 1999). Genotypes G75, G83 and EC1 were reported as tolerant to late sowing of early May (Abdalla, 2013). In 2010 season, the nine parents were crossed in a factorial mating design II, containing 5 female (G80, G86, G90, EC1 and EC2) and 4 (G83, G75, PS6 and PS7) male parents. The female parents were selected purposely to keep the majority of genetic makeup of Egyptian well-adapted genotypes together with introducing genes related to late growing conditions from the Pima (Percy and Turcotte 1988) and obsolete pollen parents (Abdalla, 2013). Selfing of the resultant $20 \mathrm{~F}_{1}$ 's to produce $\mathrm{F}_{2}, \mathrm{~s}$ was done in 2011 season. In 2012 growing season, the $20 \mathrm{~F} 2$ crosses along with their 9 parental genotypes were evaluated in two adjacent experiments, one for each planting date at Cairo University Experimental Station. The planting dates were March18 designated as full season system or conventional $\mathrm{CN}\left(\mathrm{D}_{1}\right)$ and May15 for late planting cropping system (LP) or short season system $\left(D_{2}\right)$.

\subsection{Data collected and statistical analysis}

The analysis of variance for growth, earliness, and yield variables were made using separate populations, each representing individual sowing date. Experimental design was randomized complete block design (RCBD) with four replications for each date. Each block contained 58 plots; the plot was two rows of $4 \mathrm{~m}$ long and $0.6 \mathrm{~m}$ wide. Hills were $0.25 \mathrm{~m}$ apart to insure 16 hills per row. At seedling stage, hills were thinned to keep a constant stand of one plant per hill in the two planting dates. Ten individual random guarded plants (5 from each row) were marked for traits identification. Data for growth and earliness variables were collected from five plants. These data were plant height $(\mathrm{PH})$, node number of first fruiting branch (FFN), number of fruiting branches per plant $(\mathrm{NFB} / \mathrm{p})$, days from planting to the first flower (DFF) and to the first boll (DFB). The other five plants were hand harvested at three frequent intervals until all bolls were harvested. Seed cotton yield (SC/p) was estimated in grams per plant. Earliness index (EI)-ratio of weight of seed cotton harvested at the first picking to total weight of seed cotton harvested, was expressed as a percentage. Late planting susceptibility index " $S$ " was evaluated as the relative reduction in cotton yield from $(\mathrm{CN})$ planting to (LP) planting using the following formula developed by Fischer and Maurer (1978).

$$
\mathrm{S}=\left(1-\frac{\mathrm{Y}}{\mathrm{Y}_{\mathrm{p}}}\right) /\left(1-\frac{\mathrm{X}}{\mathrm{X}_{\mathrm{p}}}\right),
$$

where: $Y=$ mean performance for a trait of a genotype grown in LP environment, $Y_{p}=$ mean performance for a trait of a genotype grown in $\mathrm{CN}$ environment. $\left(1-\frac{\mathrm{X}}{\mathrm{X}_{\mathrm{p}}}\right)=$ stress intensity, $\mathrm{X}=$ mean of $Y$ of all genotypes and $X_{p}=$ mean $Y_{p}$ of all genotypes. The scale of " $\mathrm{S}$ " rating was suggested and applied by Khanna and Viswana (1999) to characterize the genotypes relative late planting stress tolerance. $\mathrm{S}<0.5=$ high $(\mathrm{H})$ stress tolerant, $0.5<\mathrm{S}<1=$ moderate $(\mathrm{M})$ stress tolerant, and $\mathrm{S}>1=$ susceptible. The collected data were subjected to a regular analysis of variance using RCBD with four replications. Factorial crossing Design (NCDII) Scheme (Comstock and Robinson, 1948) was employed for crossing technique and estimating genetic variation in the $F_{2}$ populations. Mean performance, late planting susceptibility index, and genetic parameters were estimated on the data plot mean. Statistical analysis was done using authentic versions of Excel under windows and IRRESTAT (2005).

\section{RESULTS AND DISCUSSION 3.1. Components of genetic variability}

The factorial mating design offered a chance for partitioning genetic components into covariance of half-sib males and females, covariance of full-sibs, and estimates of combining ability components (Table 1).

Many reports revealed the magnitude of vigourness in the $F_{2}$ cotton populations that, in turn, created a desire for their utilization as commercial varieties. Given that, with other assumptions discussed in details by Tang et al. (1996), data of the $F_{2}$ are employed for estimating types of gene action and the components of variation due to combining ability.

Partitioning crosses mean square variance into $\mathrm{MS}_{\text {females}}$, MS males, and $\mathrm{MS}_{f m}$ showed that parental materials mean squares were significant for all characters, pointing out that most variability generated in the crosses was due to the effect of both parental materials regardless of the magnitude of the individual contribution in total summation of squares. The significance of both general combining ability (males and females) and specific combining ability (males $\mathrm{X}$ females) in most traits across both CN and LP environments indicated that both additive and dominance gene effects were much influenced 
by environments. Moreover, such significance in $\mathrm{MS}_{f m}$ indicated that specific cross combinations were differentially superior over others. The full analysis of variance of the model that indicated significant variation due to sowing date, parents, genotypes and their interactions was discussed elsewhere (Abdalla, 2014).

The plant breeder main interest is to separate the character phenotypic expression into its component parts i.e., genetic (additive and nonadditive) and environmental. Results presented in Table (1) showed that variances due to GCA were larger in magnitude than variances due to SCA only for FFN, DFF (LP), and DFB (LP); the remained traits showed greater variances of SCA. These results are supported by the ratios obtained for relative importance (RI) of additive to non-additive variance (Baker, 1978). RI estimate supports that GCA was important for FFN, DFF (LP), and DFB (LP), meanwhile the majority of the genetic effects for the rest of the traits remained non-additive. Most importantly, except for DFF and DFB, the behavior of combining ability variances either for GCA or SCA and the majority of genetic parameters did not change across the two growing environments, which indicates the consistency of the inheritance of these traits under both $\mathrm{CN}$ and LP environments. This, with no doubt, will help the breeder in building reliable breeding strategy and selecting the best genotypes under either environment to improve breeding under both environments. The point is that Ceccarelli et al. (1992) argued that selection in high-yielding environments has little relevance for lowyielding environments. Van Oosterom et al. (1993) reported that selection for barley within low-yield environments was more efficient in the improvement of the low-yielding environments. Now, based on the genetic components consistence across environments for most quantitatively inherited studied traits, we may advocate that the breeding procedures aimed at improving late planting tolerance traits can be practiced with large reliability under both $\mathrm{CN}$ and LP environments.

The average degree of dominance "a" estimated for the studied characters using estimates of additive variance of males $[\mathrm{a}=$ $\left.\left(2 \sigma_{m \times f}^{2} / \sigma_{m}^{2}\right)^{1 / 2}\right]$, may be due to the fact that the purpose of the present investigation was to select the male parent which can improve earliness in the resulting hybrids without deterioration of either earliness or yield of Egyptian females.

Table (1): Variance components of the $F_{2}$ data based on factorial mating design II scheme.

\begin{tabular}{|c|c|c|c|c|c|c|c|c|c|c|c|c|c|c|}
\hline \multirow{2}{*}{$\begin{array}{c}\text { Breeding } \\
\text { parameters }\end{array}$} & \multicolumn{2}{|c|}{ FFN } & \multicolumn{2}{|c|}{ DFF } & \multicolumn{2}{|c|}{ DFB } & \multicolumn{2}{|c|}{ NFB } & \multicolumn{2}{|c|}{$\mathbf{P H}$} & \multicolumn{2}{|c|}{ SC } & \multicolumn{2}{|c|}{ EI } \\
\hline & $\mathbf{C N}$ & LP & CN & LP & $\mathrm{CN}$ & LP & $\mathbf{C N}$ & $\mathbf{P}$ & $\mathbf{C N}$ & LP & CN & LP & $\mathbf{C N}$ & LP \\
\hline$\overline{\mathbf{M S}_{f}}$ & 27.01 & 5.91 & 5.87 & 137.30 & 6.78 & 119.50 & 77.20 & 138.60 & 917.55 & 1376.90 & 001.42 & 1026.15 & 514.62 & 113.40 \\
\hline $\mathbf{M S}_{m}$ & 54.68 & 253.10 & 8.80 & 275.60 & 7.00 & 258.56 & 202.00 & 123.20 & 1312.00 & 950.14 & 546.87 & 1983.12 & 601.12 & 158.60 \\
\hline $\mathbf{M S}_{f m}$ & 0.66 & 0.64 & 10.56 & 4.13 & 20.64 & 5.34 & 24.00 & \begin{tabular}{|l|}
17.03 \\
\end{tabular} & 90.65 & 114.65 & 200.16 & 207.15 & 45.98 & 45.14 \\
\hline $\mathbf{M S}_{e}$ & 0.19 & 0.20 & 6.48 & 1.87 & 2.32 & 2.97 & 3.97 & 4.12 & 44.17 & 23.17 & 39.91 & 44.10 & 26.40 & 36.02 \\
\hline$\sigma_{A f}^{2}$ & 1.65 & 4.08 & 2.21 & 8.32 & 4.76 & 7.14 & 3.32 & 7.60 & 51.70 & 78.89 & 50.08 & 51.18 & 29.25 & 4.27 \\
\hline$\sigma_{A m}^{2}$ & 2.70 & 12.62 & 8.41 & 13.57 & 13.82 & 12.66 & 8.89 & 5.31 & 61.10 & 41.77 & 67.34 & 88.80 & 27.76 & 5.67 \\
\hline$\sigma_{g c a}^{2}$ & 0.31 & 1.17 & 0.74 & 1.55 & 1.31 & 1.40 & 0.86 & 0.93 & 8.03 & 8.70 & 8.35 & 9.91 & 4.08 & 0.71 \\
\hline$\sigma_{s c a}^{2}$ & 0.12 & 0.11 & 1.02 & 0.57 & 4.58 & 0.59 & 5.01 & 3.23 & 11.62 & 22.87 & 40.06 & 40.76 & 4.90 & 2.28 \\
\hline $\boldsymbol{\sigma}_{g c a}^{2} / \boldsymbol{\sigma}^{\prime}$ & 2.62 & 10.67 & 0.73 & 2.75 & 0.29 & 2.37 & 0.17 & 0.29 & 0.69 & 0.38 & 0.21 & 0.24 & 0.83 & 0.31 \\
\hline RI & 0.84 & 96 & .59 & 0.85 & 0.36 & 0.82 & 0.26 & 0.36 & 0.58 & 0.43 & 0.29 & 0.31 & 0.62 & 0.38 \\
\hline$\sigma_{A}^{2}$ & 0.62 & 2.35 & 1.49 & 3.10 & 2.61 & 2.80 & 1.72 & 1.85 & 16.06 & 17.41 & 16.69 & 19.82 & 8.16 & 1.41 \\
\hline$\sigma_{D}^{2}$ & 0.12 & 0.11 & 1.02 & 0.57 & 4.58 & 0.59 & 5.01 & 3.23 & 11.62 & 22.87 & 40.06 & 40.76 & 4.90 & 2.28 \\
\hline$\sigma_{e}^{2}$ & 0.05 & 0.05 & 1.62 & 0.47 & 0.58 & 0.74 & 0.99 & 1.03 & 11.04 & 5.79 & 9.98 & 11.03 & 6.60 & 9.01 \\
\hline$\sigma_{p h}^{2}$ & 0.78 & 2.51 & 4.13 & 4.14 & 7.77 & 4.14 & 7.72 & 6.11 & 38.73 & 46.07 & 66.73 & 71.61 & 19.65 & 12.70 \\
\hline$\sigma_{g}^{2}$ & 0.73 & 2.46 & 2.51 & 3.67 & 7.19 & 3.40 & 6.73 & 5.08 & 27.68 & 40.28 & 56.76 & 60.59 & 13.05 & 3.69 \\
\hline PCV & 12.07 & 34.76 & 40 & 6.17 & 6.22 & 3.62 & 28.29 & 27.24 & 26.30 & 32.64 & 92.17 & 172.85 & 40.60 & 19.09 \\
\hline \begin{tabular}{|l} 
GCV \\
\end{tabular} & 11.30 & \begin{tabular}{|l|}
34.07 \\
\end{tabular} & 3.28 & 5.47 & 5.75 & 2.97 & 24.66 & 22.65 & 18.80 & 28.54 & 78.40 & 146.25 & 26.96 & 5.55 \\
\hline $\mathbf{h}_{b}^{2}$ & 93.92 & 98.01 & 60.76 & 88.70 & 92.54 & 82.05 & 87.15 & 83.15 & 71.49 & \begin{tabular}{|l|}
87.43 \\
\end{tabular} & 85.05 & 84.60 & \begin{tabular}{|l|}
66.42 \\
\end{tabular} & 29.09 \\
\hline $\mathbf{h}_{n}^{2}$ & 78.88 & 93.62 & 36.05 & 75.04 & 33.61 & 67.73 & 22.29 & 30.34 & 41.48 & 37.79 & 25.02 & 27.68 & 41.51 & 11.13 \\
\hline 6", & 0.16 & 0.07 & 0.34 & 0.17 & 0.37 & 0.20 & 0.49 & 0.53 & 0.37 & 0.49 & 0.51 & 0.46 & 0.39 & 0.75 \\
\hline
\end{tabular}

$\mathrm{MS}_{\mathrm{f},} \mathbf{M S}_{\mathrm{m},} \mathbf{M S}_{\mathrm{fm}}$ and $\mathrm{MS}_{\mathrm{e}}$ are the mean squares of FMDII for females, males, interaction and error, respectively. $\sigma_{\mathrm{Af}}^{2}$ and $\sigma_{\mathrm{Am}}^{2}$ covariance of half sib females and males, respectively. $\sigma_{\text {gca, }}^{2} \sigma_{\text {sca }}^{2}$ and $\sigma_{\text {gca }}^{2} / \sigma_{\text {sca }}^{2}$ are variances of general and specific combining ability and their ratio, respectively. $R I=2 \sigma^{2} g /\left(2 \sigma^{2} g+\sigma^{2} s\right)$, is the relative importance of additive to non-additive variances. $\sigma_{A}^{2}, \sigma_{D}^{2}, \sigma_{e}^{2}$, $\sigma_{p h}^{2}$, and $\sigma_{g}^{2}$ are components of phenotypic variance of additive, dominance, error, phenotypic and genotypic variances, respectively. PCV and GCV are phenotypic and genotypic coefficients of variation, respectively. $h_{b}{ }_{b}$ and $h^{2}$ are broad and narrow sense heritability, respectively. "a" is the average degree of dominance $=\left[\left(2 \sigma_{\mathrm{mxf}}^{2} / \sigma_{\mathrm{m}}^{2}\right)^{1 / 2}\right]$. 
According to Nelson and Bernard (1984), a zero value of "a" indicates absence of dominance, a value larger than zero and less than unity indicates partial dominance, a value equal to unity indicates complete dominance, and a value of more than unity indicates over dominance. The negative estimates of dominance variances are considered estimates of zero. The estimates of "a" indicated the presence of partial dominance ranging from 0.07 FFN (LP) to 0.75 EI (LP). The genotypic variance was less than the phenotypic variance for all traits under both environments, which once again reflecting the consistence inheritance of these traits across environments (Table 1). Moreover, it is manifested in the increasing of the PCV over GCV and greater broad sense heretabilities (Table 1). The two estimates of coefficient of variation proved to be high for FFN (CN and LP), DFF (LP), and DFB (LP). The high values of $\mathrm{h}_{n}^{2}$ may indicate that selection for these traits under both environments during early segregating generations would be effective. The other low $\mathrm{h}_{n}^{2}$ estimates, however, revealed that the use of recurrent selection for exploiting available genetic variability is preferable. These results are relatively similar to those reported earlier by Baker and Verhalen (1975), Chahal and Singh (1978) and Esmail et al. (2005). The significance of both combining ability estimates in most traits indicated that both additive and dominance gene effects were much influenced by environments. Therefore, testing for both GCA and SCA effects at both environments along with mean performance might provide useful information that help in selecting proper LP tolerant genotypes.

\subsection{Susceptibility to late planting}

The main objective of the current study was to attain short season cotton genotypes that possess a high yielding capacity. Many previous works showed that the plant breeder cannot consider these two characters separately in cotton breeding programs. Thus, when establishing a breeding strategy for short growing season, it is important for cotton breeder to determine the potential of genetic materials to enhance the desired traits. Late planting (LP) susceptibility index "S" employed herein as a complementary criterion helps in selecting the LP tolerant genotypes apart from the effects of environment on the genetic inheritance of the studied traits.

Mean performance of growth-based earliness, yield-based earliness, and "S" index of female, male parents and their crosses as affected by planting date is presented in Tables (2 and 3). In general, mean performance of genotypes showed differential response to the planting dates.

The female lines EC1 and EC2 and the two male lines PS6 and PS7 showed a trend of significant earliness with lower first fruiting node, lower number of days to first flower, and to first boll at the two planting dates. It seemed that the tall plants showed higher FFN. Number of sympodial (fruiting) branches (NFB) declined with delaying planting date (Table 2). The maternal parents G86 and EC1 had the highest number of fruiting branches in the two dates with slight difference, while the paternal lines G83 PS6 were the first in this regard at the two dates. Pettigrew and Meredith (2009) reported that growth - based earliness traits were influenced by the prevailing weather conditions and cultural practices.

On the other hand, the nine parents showed a range of tolerance to stresses of LP based on growth-based earliness characters, i.e., FFN, DFF, and DFB. The five female lines were moderate in LP stress tolerant based on "S" index with FFN. Although most male parents were earlier in FFN, all of them were susceptible to LP stress $(\overline{\mathrm{S}}>1)$. Regarding DFF, only genotype G80 was high tolerant to LP (0.44) and appeared to impart this tolerance to all of its $F_{2}$ generation. PS6 had consistently least sympodial branch number at conventional and late-season, and genotype EC2 had the lowest FFN among females; these genotypes may be considered as the earliest at both dates based on the inherited performance of the FFN (Table 2). Among males, G83 was late based on DFF; however, it was moderately tolerant to LP. Days to first boll showed that the male parents had least mean performance (113.58 day from planting) at LP environment than female parents (119.10 days from planting). This indicated their high earliness performance in DFB; in the mean time they showed a relatively moderate " $\mathrm{S}$ " index. This trait breaks the association between high performance and high "S" index especially with genotype G83. It seems that the LP tolerant genotypes as identified by " $\mathrm{S}$ " should possess higher mean performance. However, Clarke et al. (1984) reported that a stress tolerant genotypes need not to have a high yield potential since "S" provides a measure of tolerance based on minimization of yield loss under stress rather than on yield per se. Number of fruiting branches (NFB) in Table (2) and plant height 
Table (2): Mean performance and susceptibility index (S) for earliness-based traits of factorial (NCD11) design evaluated in conventional planting $(\mathrm{CN})$ and late planting $(\mathrm{LP})$ growing conditions.

\begin{tabular}{|c|c|c|c|c|c|c|c|c|c|c|c|c|c|}
\hline \multirow{2}{*}{$\begin{array}{l}\text { Serial } \\
\text { No. }\end{array}$} & \multirow{2}{*}{$\begin{array}{l}\text { Genotypes } \\
\text { Females }\end{array}$} & \multicolumn{3}{|c|}{ FFN } & \multicolumn{3}{|c|}{ DFF } & \multicolumn{3}{|c|}{ DFB } & \multicolumn{3}{|c|}{ NFB } \\
\hline & & $\mathbf{C N}$ & LP & $\mathbf{S}$ & $\mathbf{C N}$ & LP & $\mathbf{S}$ & $\mathbf{C N}$ & $\mathbf{L P}$ & $\mathbf{S}$ & $\mathrm{CN}$ & LP & $\mathbf{S}$ \\
\hline 1 & G86 & 7.80 & 8.30 & 0.50 & 76.20 & 69.60 & 0.72 & 129.90 & 117.00 & 1.20 & 28.20 & 25.60 & 0.58 \\
\hline 2 & EC1 & 6.60 & 8.20 & 1.91 & 81.50 & 72.60 & 0.90 & 128.10 & 119.10 & 0.85 & 26.80 & 23.20 & 0.85 \\
\hline 3 & G90 & 8.10 & 8.90 & 0.78 & 81.30 & 72.20 & 0.93 & 131.40 & 120.40 & 1.01 & 23.60 & 22.80 & 0.21 \\
\hline 4 & EC2 & 6.40 & 7.10 & 0.86 & 76.30 & 65.90 & 1.13 & 129.30 & 117.70 & 1.08 & 24.80 & 19.10 & 1.45 \\
\hline \multirow[t]{3}{*}{5} & G80 & 7.70 & 8.50 & 0.82 & 78.70 & 74.50 & 0.44 & 131.00 & 121.30 & 0.89 & 28.20 & 24.90 & 0.74 \\
\hline & Mean & 7.32 & 8.20 & 0.97 & 78.80 & 70.96 & 0.82 & 129.94 & 119.10 & 1.00 & 26.32 & 23.12 & 0.77 \\
\hline & Males & & & & & & & & & & & & \\
\hline 1 & PS6 & 4.20 & 4.80 & 1.12 & 69.70 & 59.70 & 1.19 & 114.50 & 104.80 & 1.02 & 26.90 & 24.90 & 0.47 \\
\hline 2 & PS7 & 6.30 & 7.70 & 1.75 & 78.50 & 64.50 & 1.47 & 123.80 & 113.80 & 0.97 & 23.90 & 18.70 & 1.38 \\
\hline 3 & G83 & 7.20 & 8.60 & 1.53 & 76.30 & 70.60 & 0.62 & 123.70 & 116.90 & 0.66 & 22.10 & 20.80 & 0.37 \\
\hline \multirow[t]{3}{*}{4} & G75 & 5.90 & 6.90 & 1.33 & 77.50 & 66.50 & 1.17 & 126.70 & 118.80 & 0.75 & 24.90 & 23.80 & 0.28 \\
\hline & Mean & 5.90 & 7.00 & 1.44 & 75.50 & 65.33 & 1.11 & 122.18 & $\begin{array}{l}113.58 \\
\end{array}$ & 0.85 & 24.45 & 22.05 & 0.62 \\
\hline & $\mathrm{F}_{2}$ Crosses & & & & & & & & & & & & \\
\hline 1 & G86xPS6 & 5.84 & 5.53 & 0.0 & 72.47 & 62.65 & 1.12 & 120.94 & 108.77 & 1.21 & 30.55 & 27.90 & 0.55 \\
\hline 2 & G86xPS7 & 6.17 & 6.37 & 0.26 & 76.90 & 69.53 & 0.79 & 125.34 & 118.34 & 0.67 & 31.65 & 20.82 & 2.17 \\
\hline 3 & $86 x G 83$ & 6.97 & 8.20 & 1.39 & 77.50 & 66.48 & 1.18 & 124.67 & 113.94 & 1.04 & 27.79 & 26.73 & 0.24 \\
\hline 4 & G86xG75 & 6.29 & 6.80 & 0.64 & 75.48 & 67.50 & 0.87 & 125.64 & 114.46 & 1.07 & 34.09 & 29.03 & 0.94 \\
\hline 5 & EC1xPS6 & 5.40 & 6.01 & 0.89 & 75.50 & 62.09 & 1.47 & 119.78 & 110.64 & 0.92 & 27.63 & 20.89 & 1.54 \\
\hline 6 & EC1xPS7 & 6.10 & 6.65 & 0.71 & 78.60 & 67.50 & 1.17 & 126.88 & 119.92 & 0.66 & 28.44 & 20.94 & 1.67 \\
\hline 7 & EC1xG83 & 6.85 & 7.85 & 1.15 & 79.50 & 68.45 & 1.15 & 128.46 & 114.74 & 1.29 & 26.71 & 21.77 & 1.17 \\
\hline 8 & EC1xG75 & 6.35 & 6.85 & 0.62 & 79.07 & 69.50 & 1.00 & $\mathbf{1 2 7 . 7 6}$ & 116.80 & 1.03 & 28.83 & 25.56 & 0.72 \\
\hline 9 & G90xPS6 & 5.52 & 6.18 & 0.94 & 73.70 & 61.73 & 1.34 & 118.69 & 109.91 & 0.89 & 23.74 & 22.15 & 0.42 \\
\hline 10 & G90xPS7 & 6.55 & 6.35 & 0.00 & 77.50 & 62.50 & 1.60 & 131.98 & 119.76 & 1.12 & 25.91 & 19.62 & 1.54 \\
\hline 11 & G90xG83 & 6.89 & 7.82 & 1.06 & 76.49 & 65.34 & 1.20 & 125.65 & 112.77 & 1.24 & 22.59 & 20.74 & 0.52 \\
\hline 12 & G90xG75 & 7.45 & 8.52 & 1.13 & 78.55 & 72.80 & 0.60 & 126.76 & 112.81 & 1.33 & 30.63 & 27.76 & 0.59 \\
\hline 13 & EC2xPS6 & 5.29 & 4.85 & 0.00 & 73.62 & 60.50 & 1.47 & 117.81 & 106.88 & 1.12 & 23.25 & 16.80 & 1.76 \\
\hline 14 & EC2xPS7 & 6.80 & 8.03 & 1.42 & 76.47 & 67.60 & 0.96 & 124.74 & 113.69 & 1.07 & 30.76 & 21.60 & 1.88 \\
\hline 15 & EC2xG83 & 6.79 & 7.85 & 1.23 & 75.60 & 67.50 & 0.89 & 122.63 & 112.67 & 0.98 & 25.87 & 23.72 & 0.53 \\
\hline 16 & EC2xG75 & 6.15 & 6.25 & 0.13 & 77.57 & 66.61 & 1.17 & 128.75 & 114.90 & 1.30 & 30.69 & 18.93 & 2.43 \\
\hline 17 & G80xPS6 & 5.81 & 6.85 & 1.41 & 68.49 & 66.50 & 0.24 & 122.88 & 111.72 & 1.09 & 21.79 & 20.89 & 0.26 \\
\hline 18 & G80xPS7 & 6.77 & 8.74 & 2.29 & 77.50 & 70.49 & 0.75 & 125.71 & 115.84 & 0.95 & 24.73 & 17.91 & 1.75 \\
\hline 19 & G80xG83 & 7.03 & 9.42 & 2.68 & 78.62 & 73.08 & 0.58 & 125.54 & 117.69 & 0.75 & 23.13 & 19.94 & 0.87 \\
\hline \multirow[t]{4}{*}{20} & G80xG75 & 8.15 & 9.35 & 1.16 & 80.50 & 72.80 & 0.79 & 128.70 & 120.76 & 0.74 & 26.94 & 24.95 & 0.47 \\
\hline & Mean & 6.46 & 7.22 & 0.89 & 76.48 & 67.06 & 1.02 & 124.97 & 114.35 & 1.02 & 27.29 & 22.43 & 1.10 \\
\hline & $\operatorname{LSD}(0.05)$ & 0.62 & 0.63 & & 3.60 & 1.93 & & 2.15 & 2.44 & & 2.82 & 2.87 & \\
\hline & $\operatorname{LSD}(0.01)$ & 0.82 & 1.68 & & 4.78 & 2.56 & & 2.86 & 3.24 & & 3.75 & 3.82 & \\
\hline
\end{tabular}

FFN; the node number of first fruiting branch or first fruiting node, DFF; days to first flower, DFB; days to first boll and NFB; days to first branch.

(PH) in Table (3) of both parental materials were decreased with delaying $\mathrm{PD}$. With respect to NFB, genotype G90 among females and G75 among males had high tolerance to LP, whereas genotype EC2 (among males) and PS7 ( among females) were susceptible to LP conditions. The remained parental materials were moderately tolerant to LP. Godoy and Palomo (1999) reported that the lower FFN and the shorter $\mathrm{PH}$, the earlier were the DFF and DFB. The results also revealed that genotypes PS6 and G75 established earlier fruit set with delayed planting that contributed to the decreased plant height as early fruiting structures consume plant resources, whereas genotypes G86 and EC1 showed large vegetative growth manifested in tall plants associated with delayed planting. Keim et al. (1985) reported that plants of early maturing ( $G$. hirsutum) developed for short growing seasons are generally smaller than those developed for longer growing seasons.

Seed cotton yield/plant for parental materials ranged from 25.40 to $39.80 \mathrm{~g}$ in LP conditions (Table 3). Genotypes G90 (among females), and PS6 (among males) had the highest seed cotton yielders at LP. The "S" values based on seed cotton yield revealed that the female line G90 (0.49) showed the lowest "S" index among parental materials and thus it was identified as a high LP stress tolerant. Moderately LP stress tolerance was recorded by genotypes EC2 (G77 $\mathrm{x}$ PS6), PS6 and G75. The remaining parents were susceptible to LP where $\mathrm{S}$ was greater than unity. Regarding EI, genotypes G90, EC2, PS6 and PS7 were identified as high stress tolerant; genotypes G86, G83 were identified as 
moderately LP tolerant, and genotypes EC1, G80, G75 were susceptible to LP. Genotypes G90, PS6 and G75 were identified as LP tolerant; meanwhile they were of high yield potential compared to others, indicating that stress tolerance was due to high yield potential and low S index (Ehdaie et al. 1988).

\subsection{Crosses potential and $L P$ tolerance}

The average node number of first fruiting branch (FFN) of the crosses was increased by delaying sowing date (Table 2).

Average number of days from emergence to first flower and to first open boll was significantly affected by planting date. Cotton planted in middle March produced flowers as late as 75.6 day from planting compared with 67.06 day for cotton planted in middle May.
March planting produced bolls as late as 124 day compared with 114 day in May plantings. Number of sympodial declined with delaying planting date (Table 3). The maximum number of sympodial branches was recorded by the crosses G86 x G75, G86 x PS7, and G90 x G75 at the two growing dates. The plant stature of crosses was moderate between the parental plants with slight decrease by delaying PD. The crosses G80 x G75 $(163 \mathrm{~cm})$, EC1 x PS7 $(162 \mathrm{~cm})$ were the tallest at $D_{1}$. The group of crosses included PS6 was shorter than the other crosses, the cross EC2 $\times$ PS6 was the shortest between and within the two growing dates. Seed cotton (SC/p) averaged across crosses was 72.09 and $41.43 \mathrm{~g}$ at $\mathrm{D}_{1}$ and $\mathrm{D}_{2}$, respectively. Early sowing allowed longer growing season and gave

Table (3): Mean performance and susceptibility index (S) for plant height (PH) and yield-based earliness traits of factorial (NCD11) design evaluated in conventional planting $(\mathrm{CN})$ and late planting (LP) growing conditions.

\begin{tabular}{|c|c|c|c|c|c|c|c|c|c|c|}
\hline \multirow{2}{*}{$\begin{array}{c}\text { Serial } \\
\text { No. }\end{array}$} & \multirow{2}{*}{$\begin{array}{c}\text { Genotypes } \\
\text { Females }\end{array}$} & \multicolumn{3}{|c|}{ PH } & \multicolumn{3}{|c|}{ SC } & \multicolumn{3}{|c|}{ EI } \\
\hline & & D1 & D2 & $\mathbf{S}$ & D1 & D2 & $\mathbf{S}$ & D1 & D2 & $\mathbf{S}$ \\
\hline 1 & G86 & 173.00 & 151.30 & 2.46 & $\mathbf{5 0 . 5 0}$ & 26.20 & 1.12 & 37.40 & 48.70 & 0.88 \\
\hline 2 & EC1 & 169.00 & 158.80 & 1.18 & 58.40 & 27.50 & 1.23 & 45.30 & 68.10 & 1.46 \\
\hline 3 & G90 & 161.60 & 142.80 & 2.28 & 50.40 & 39.70 & 0.49 & 56.40 & 63.20 & 0.35 \\
\hline 4 & EC2 & 143.90 & 144.10 & 0.03 & 61.20 & 36.60 & 0.94 & 51.00 & 58.00 & 0.40 \\
\hline \multirow[t]{3}{*}{5} & G80 & 158.00 & 144.70 & 1.65 & 65.40 & 32.90 & 1.16 & 41.70 & 62.80 & 1.47 \\
\hline & Mean & 161.10 & 148.34 & 1.51 & 57.18 & 32.58 & 0.99 & 46.36 & 60.16 & 0.91 \\
\hline & Males & & & & & & & & & \\
\hline 1 & PS6 & 131.40 & 127.80 & 0.54 & 60.70 & 39.80 & 0.80 & 57.40 & 63.40 & 0.30 \\
\hline 2 & PS7 & 141.80 & 143.90 & 0.00 & 61.30 & 34.30 & 1.02 & 52.70 & 60.10 & 0.41 \\
\hline 3 & G83 & 147.90 & 132.90 & 1.99 & 69.70 & 25.40 & 1.48 & 45.30 & 58.10 & 0.82 \\
\hline \multirow[t]{3}{*}{4} & G75 & 149.80 & 132.90 & 2.21 & 56.30 & 39.00 & 0.71 & 39.40 & 63.20 & 1.75 \\
\hline & Mean & 142.73 & 134.38 & 1.11 & 62.00 & 34.63 & 1.00 & 48.70 & 61.20 & 0.82 \\
\hline & $\mathbf{F}_{2}$ Crosses & & & & & & & & & \\
\hline 1 & G86xPS6 & 137.87 & 140.90 & 0.00 & 78.65 & 43.92 & 1.03 & 47.35 & 68.33 & 1.28 \\
\hline 2 & G86xPS7 & 143.71 & 133.71 & 1.36 & 68.84 & 33.90 & 1.18 & 42.79 & 68.45 & 1.74 \\
\hline 3 & $86 \times 683$ & 158.67 & 141.85 & 2.08 & 82.42 & 44.90 & 1.06 & 39.56 & 70.30 & 2.25 \\
\hline 4 & G86xG75 & 159.75 & 144.97 & 1.81 & 88.87 & 54.23 & 0.91 & 32.34 & 32.57 & 0.02 \\
\hline 5 & EC1xPS6 & 142.76 & 137.34 & 0.74 & 62.61 & 33.14 & 1.10 & 46.39 & 72.03 & 1.60 \\
\hline 6 & EC1xPS7 & 166.58 & 155.54 & 1.30 & 72.76 & 40.78 & 1.02 & 46.50 & 63.22 & 1.04 \\
\hline 7 & EC1xG83 & 158.55 & 151.87 & 0.83 & 72.68 & 39.43 & 1.06 & 47.39 & 68.42 & 1.29 \\
\hline 8 & EC1xG75 & 157.64 & 153.90 & 0.47 & 57.08 & 28.26 & 1.17 & 42.75 & 57.22 & 0.98 \\
\hline 9 & G90xPS6 & 138.92 & 134.55 & 0.62 & 59.77 & 36.13 & 0.92 & 59.33 & 71.24 & 0.58 \\
\hline 10 & G90xPS7 & 145.83 & 137.87 & 1.07 & 67.83 & 35.50 & 1.11 & 52.51 & 67.56 & 0.83 \\
\hline 11 & G90xG83 & 140.96 & 137.69 & 0.45 & 71.00 & 41.36 & 0.97 & 62.39 & 67.27 & 0.23 \\
\hline 12 & G90xG75 & 145.77 & 139.92 & 0.79 & 81.88 & 52.73 & 0.83 & 54.61 & 77.44 & 1.21 \\
\hline 13 & EC2xPS6 & 120.84 & 109.97 & 1.76 & 62.52 & 34.97 & 1.03 & 60.72 & 67.29 & 0.31 \\
\hline 14 & EC2xPS7 & 137.92 & 140.63 & -0.39 & 75.40 & 44.38 & 0.96 & 46.45 & 67.18 & 1.29 \\
\hline 15 & EC2xG83 & 139.95 & 124.85 & 2.12 & 79.90 & 45.35 & 1.01 & 47.39 & 65.31 & 1.10 \\
\hline 16 & EC2xG75 & 143.79 & 166.74 & 0.00 & 78.79 & 39.85 & 1.15 & 51.30 & 69.25 & 1.01 \\
\hline 17 & G80xPS6 & 140.69 & 135.66 & 0.70 & 66.57 & 41.84 & 0.86 & 55.61 & 72.31 & 0.87 \\
\hline 18 & G80xPS7 & 144.86 & 134.57 & 1.39 & 70.64 & 45.84 & 0.82 & 49.86 & 76.50 & 1.55 \\
\hline 19 & G80xG83 & 151.69 & 147.68 & 0.52 & 76.40 & 47.92 & 0.87 & 44.37 & 65.47 & 1.38 \\
\hline \multirow[t]{4}{*}{20} & G80xG75 & 167.97 & 152.70 & 1.78 & 73.31 & 44.14 & 0.93 & 38.44 & 63.19 & 1.87 \\
\hline & Mean & 147.24 & 141.15 & 0.79 & 72.40 & 41.43 & 1.00 & 48.40 & 66.53 & 1.12 \\
\hline & $\operatorname{LSD}(0.05)$ & 9.40 & 6.78 & & 9.84 & 10.67 & & 7.26 & 8.48 & \\
\hline & $\operatorname{LSD}(0.01)$ & 12.50 & 9.02 & & 11.10 & 12.90 & & 9.65 & 11.27 & \\
\hline
\end{tabular}

PH; plant height, NFB/P; numbers of fruiting branches, EI; earliness index, and SC/p; seed cotton yield per plant. 
enough time to develop a heavy boll load and seed cotton yield (Pettigrew and Meredith, 2009). The "S" values based on $S C / p$ revealed that the cross combinations No. 4, 9, 12, 17, 18, 19 and 20 showed moderate LP stress tolerance (Table 3).

The crosses No. 4, 12, 18, and 19 had the highest yield potential at $\mathrm{D}_{2}$. It seemed that the LP tolerant genotypes as identified by "S" should possess tolerance mechanisms associated with higher yield potential for the development of high yielding and LP tolerant cultivars. However, Clarke et al. (1984) reported that a stress tolerant genotype does not need a high yield potential since "S" provides a measure of tolerance based on minimization of yield loss under stress rather than on stress yield per se. At least three of the highest six EI crosses at the two sowing dates contained PS6 as a common parent. The crosses No. 11, 13, and 9 were significantly the highest in EI at $\mathrm{D}_{1}$, whereas the crosses No. 16, 18, and 17 were the highest in EI at $\mathrm{D}_{2}$. The cross combinations between high yielder genotypes were not always introduces high yielder crosses (Abdalla et al., 2007), which emphasize the importance of investigating combining ability effects along with the mode of inheritance under the targeted environment.

\subsection{General combining ability effects}

Table (4) presented estimates of GCA effects for parental lines and SCA effects for crosses as affected by planting environment. These estimates were tested for significance against the appropriate standard errors in forms of LSD. The negative GCA effects would be of interest in the growth-based earliness traits; whereas the

Table (4): Estimates of GCA and SCA effects for growth-based and yield-based earliness traits at the two studied environments

\begin{tabular}{|c|c|c|c|c|c|c|c|c|c|c|c|c|c|c|}
\hline \multicolumn{15}{|c|}{ GCA } \\
\hline & FFN & & DFF & & DFB & & NFB & & $\mathbf{P H}$ & & SC & & EI & \\
\hline Females & $\mathbf{C N}$ & $\mathbf{L P}$ & $\mathbf{C N}$ & $\mathbf{L P}$ & $\mathbf{C N}$ & $\mathbf{L P}$ & $\mathbf{C N}$ & $\mathbf{L P}$ & $\mathbf{C N}$ & LP & $\mathbf{C N}$ & LP & $\mathbf{C N}$ & LP \\
\hline G86 & -0.14 & -0.50 & \begin{tabular}{|l|}
-0.89 \\
\end{tabular} & -0.52 & -0.82 & -0.47 & 3.73 & 3.69 & 2.76 & -0.79 & 7.30 & 2.81 & -7.89 & -6.62 \\
\hline EC1 & -0.28 & -0.38 & 1.69 & $\begin{array}{l}-0.17 \\
\end{array}$ & 0.75 & 1.18 & 0.61 & \begin{tabular}{|l|}
-0.14 \\
\end{tabular} & 9.14 & 8.51 & -6.12 & -6.03 & -2.64 & -1.31 \\
\hline G90 & \begin{tabular}{|l|l|}
0.14 \\
\end{tabular} & \begin{tabular}{|l|}
0.00 \\
\end{tabular} & 0.08 & -1.47 & 0.80 & -0.54 & -1.57 & 0.14 & -4.37 & -3.64 & -2.28 & 0.00 & 8.81 & 4.35 \\
\hline EC2 & -0.20 & -0.48 & -0.67 & -1.51 & -1.49 & -2.32 & 0.35 & -2.17 & -11.62 & -5.60 & 1.75 & -0.29 & 3.07 & 0.73 \\
\hline G80 & 0.48 & 1.37 & -0.20 & 3.66 & 0.74 & 2.15 & -3.14 & -1.51 & 4.06 & 1.50 & -0.67 & 3.50 & -1.33 & 2.84 \\
\hline LSD0.05(g) & 0.22 & 0.22 & 1.27 & 0.68 & 0.29 & 0.86 & 1.02 & 1.05 & 3.32 & 2.40 & 3.16 & 3.32 & 2.57 & 3.00 \\
\hline LSD0.05(g-g) & 0.31 & 0.32 & 1.80 & 0.97 & 1.08 & 1.22 & 1.40 & 1.44 & 4.70 & 3.40 & 4.46 & 4.70 & 3.63 & 4.24 \\
\hline \multicolumn{15}{|l|}{ Males } \\
\hline PS6 & -0.89 & -1.34 & -3.72 & -4.37 & -4.95 & -4.77 & -1.90 & \begin{tabular}{|l|}
-0.70 \\
\end{tabular} & -11.02 & -9.47 & -6.38 & -3.43 & 5.48 & 3.71 \\
\hline PS7 & \begin{tabular}{|l|}
0.02 \\
\end{tabular} & \begin{tabular}{|l|}
0.01 \\
\end{tabular} & 0.91 & 0.46 & 1.96 & 3.16 & 1.01 & -2.25 & 0.54 & -0.69 & -1.31 & -1.35 & \begin{tabular}{|l|}
-0.78 \\
\end{tabular} & 2.05 \\
\hline G83 & 0.45 & 1.01 & 1.06 & 1.11 & 0.42 & 0.01 & -2.07 & 0.15 & 2.72 & -0.36 & 4.08 & 2.36 & -0.18 & 0.82 \\
\hline G75 & 0.42 & \begin{tabular}{|l|}
0.33 \\
\end{tabular} & 1.75 & 2.78 & 2.55 & 1.60 & 2.95 & 2.82 & 7.74 & 10.50 & 3.59 & 2.41 & -4.51 & -6.60 \\
\hline LSD0.05(g) & \begin{tabular}{|l|}
0.20 \\
\end{tabular} & \begin{tabular}{|l|}
0.20 \\
\end{tabular} & 1.13 & 0.60 & 0.48 & 0.78 & 1.17 & 0.90 & 2.98 & 2.14 & 2.82 & 2.96 & 2.30 & 2.28 \\
\hline LSD0.05(g-g) & 0.27 & 0.28 & 1.60 & 0.86 & 0.96 & 1.08 & 1.26 & 1.28 & 4.20 & 3.04 & 4.00 & 4.20 & 3.24 & 3.80 \\
\hline \multicolumn{15}{|c|}{ SCA } \\
\hline G86x & 0.41 & 0.14 & 0.61 & 0.48 & 1.74 & -5.58 & 1.43 & 2.48 & \begin{tabular}{|l|}
-1.11 \\
\end{tabular} & 10.01 & 5.33 & 3.11 & 1.36 & 4.71 \\
\hline \begin{tabular}{|l|} 
G86xPS7 \\
\end{tabular} & -0.17 & -0.36 & 0.40 & 2.53 & -0.77 & 3.99 & -0.38 & -3.05 & \begin{tabular}{|l|}
-6.83 \\
\end{tabular} & -5.96 & -9.55 & -8.99 & 3.06 & 6.49 \\
\hline $86 x G 83$ & \begin{tabular}{|l|}
0.21 \\
\end{tabular} & \begin{tabular}{|l|l|}
0.47 \\
\end{tabular} & 0.85 & -1.17 & 0.10 & -0.41 & -1.16 & \begin{tabular}{|l|}
0.46 \\
\end{tabular} & \begin{tabular}{|l|}
5.95 \\
\end{tabular} & 1.85 & -1.35 & -1.70 & -0.77 & 9.56 \\
\hline \begin{tabular}{|l|l|} 
G86xG75 \\
\end{tabular} & -0.45 & \begin{tabular}{|l|}
-0.26 \\
\end{tabular} & -1.86 & -1.82 & -1.06 & 0.11 & 0.12 & 0.09 & 2.01 & -5.88 & 5.59 & 7.58 & -3.66 & -20.75 \\
\hline EC1xPS6 & \begin{tabular}{|l|}
0.11 \\
\end{tabular} & \begin{tabular}{|l|}
0.51 \\
\end{tabular} & 1.06 & -0.43 & -0.99 & -3.71 & \begin{tabular}{|l|}
1.63 \\
\end{tabular} & \begin{tabular}{|l|}
-0.70 \\
\end{tabular} & -2.60 & -2.86 & 2.70 & 1.16 & -4.85 & 3.10 \\
\hline EC1x & .09 & -0.20 & -0.48 & 0.15 & -0.80 & 5.57 & -0.47 & \begin{tabular}{|l|}
0.90 \\
\end{tabular} & 9.66 & 6.56 & 7.78 & 6.73 & 1.52 & -4.05 \\
\hline EC1xG83 & 0.23 & \begin{tabular}{|l|}
0.00 \\
\end{tabular} & \begin{tabular}{|l|}
0.27 \\
\end{tabular} & 0.46 & 2.32 & 0.39 & \begin{tabular}{|l|l|}
0.88 \\
\end{tabular} & -0.67 & \begin{tabular}{|l|}
-0.56 \\
\end{tabular} & 2.57 & 2.32 & 1.67 & 1.81 & 2.37 \\
\hline EC1xG75 & -0.24 & -0.32 & -0.85 & -0.17 & -0.51 & 2.45 & -2.02 & 0.45 & -6.49 & -6.26 & -12.79 & -9.55 & 1.50 & -1.41 \\
\hline G90xPS6 & \begin{tabular}{|l|}
-0.19 \\
\end{tabular} & \begin{tabular}{|l|}
0.30 \\
\end{tabular} & 0.86 & 0.50 & -2.13 & -4.44 & -0.08 & 0.29 & 7.07 & 6.51 & -3.97 & -1.87 & -3.36 & -3.35 \\
\hline G90xPS7 & \begin{tabular}{|l|}
-0.07 \\
\end{tabular} & \begin{tabular}{|l|}
-0.88 \\
\end{tabular} & 0.03 & -3.56 & 4.25 & 5.41 & -0.82 & \begin{tabular}{|l|}
-0.70 \\
\end{tabular} & 2.42 & 1.05 & -0.98 & -4.58 & -3.92 & -5.37 \\
\hline G90xG83 & -0.16 & -0.41 & -1.13 & -1.36 & -0.54 & -1.58 & -1.06 & -1.98 & -4.63 & 0.54 & -3.20 & -2.43 & 5.36 & -4.43 \\
\hline G90xG75 & \begin{tabular}{|l|}
0.43 \\
\end{tabular} & \begin{tabular}{|l|}
0.97 \\
\end{tabular} & 0.24 & 4.43 & -1.56 & -1.54 & 1.97 & 2.38 & \begin{tabular}{|l|}
-4.84 \\
\end{tabular} & -8.08 & 8.17 & 8.89 & 1.91 & 13.16 \\
\hline EC2xPS6 & \begin{tabular}{|c|}
-0.08 \\
\end{tabular} & -0.56 & 1.53 & -0.69 & -0.72 & -7.47 & -2.49 & -2.76 & -3.76 & -16.11 & -5.26 & -2.74 & 3.78 & -3.68 \\
\hline EC2xPS7 & 0.52 & \begin{tabular}{|l|}
1.28 \\
\end{tabular} & -0.26 & 1.58 & -0.70 & -0.66 & 2.11 & 3.59 & 1.76 & 5.77 & 2.55 & 4.59 & -4.24 & -2.13 \\
\hline EC2xG83 & \begin{tabular}{|l|}
0.09 \\
\end{tabular} & \begin{tabular}{|l|}
0.10 \\
\end{tabular} & -1.28 & 0.84 & -1.27 & -1.68 & \begin{tabular}{|l|}
0.30 \\
\end{tabular} & 3.31 & 1.60 & -10.34 & 1.67 & 1.85 & -3.90 & -2.77 \\
\hline EC2xG75 & \begin{tabular}{|l|}
-0.53 \\
\end{tabular} & \begin{tabular}{|l|}
-0.83 \\
\end{tabular} & \begin{tabular}{|l|}
0.00 \\
\end{tabular} & -1.72 & 2.72 & 0.55 & \begin{tabular}{|l|}
0.10 \\
\end{tabular} & -4.15 & 0.42 & 20.70 & 1.05 & -3.70 & 4.35 & 8.59 \\
\hline \begin{tabular}{|l} 
G80xPS6 \\
\end{tabular} & -0.24 & -0.40 & -4.06 & 0.15 & 2.12 & -2.63 & -0.46 & 0.67 & \begin{tabular}{|l|}
0.41 \\
\end{tabular} & 2.47 & 1.22 & 0.34 & 3.06 & -0.77 \\
\hline G80xPS7 & -0.19 & 0.14 & \begin{tabular}{|l|}
0.31 \\
\end{tabular} & -0.69 & -1.96 & 1.49 & -0.43 & -0.76 & -6.98 & -7.40 & 0.22 & 2.25 & 3.57 & 5.08 \\
\hline G80xG83 & -0.36 & -0.18 & 1.28 & 1.25 & -0.59 & 3.34 & 1.05 & -1.13 & \begin{tabular}{|l|}
-2.34 \\
\end{tabular} & 5.39 & 0.59 & 0.63 & -2.52 & -4.72 \\
\hline G80xG75 & 0.79 & 0.43 & 2.47 & -0.70 & 0.44 & 6.41 & -0.15 & 1.21 & 8.92 & -0.45 & -2.01 & -3.21 & -4.12 & 0.42 \\
\hline LSD0 & 0.43 & 0.45 & 2.54 & 1.37 & 1.52 & 1.72 & 1.98 & 2.03 & 6.64 & 4.80 & 6.32 & 6.64 & 5.14 & 6.00 \\
\hline LSD0.05(Sij-Skl) & \begin{tabular}{|l|}
0.62 \\
\end{tabular} & 0.63 & 3.60 & 1.94 & 2.15 & 2.44 & 2.82 & 2.88 & 9.40 & 6.98 & 8.94 & 9.40 & 7.29 & 8.48 \\
\hline
\end{tabular}


positive effects for NFB, yield and earliness would be useful for the breeder. For plant height, the study would prefer to select short plants to be earlier as suggested by Godoy and Palomo (1999). Maternal parent EC2 as well as the paternal parent PS6 gave highly significant desired GCA effects for growth-based traits (FFN, DFF, DFB, and $\mathrm{PH}$ ) at $\mathrm{D}_{1}$ and $\mathrm{D}_{2}$ with little differences; meanwhile, they showed significant desired GCA effects for EI at the two planting dates (Table 4). These two lines would be considered as good general combiners for developing earlier genotypes; the crosses involved those parents are expected to have a good chance for introducing improved descendants. The female parent G90 was a good combiner for earliness index at the two dates. Such genotypes could be involved in a crossing program to improve growth traits for short planting season. Moreover, the two introducedbarbadense genotypes P6 and P7 were good general combiners for the majority of earliness traits. Abdalla et al. (1999, 2007) reported significant GCA effects for earliness in a diallel mating system among barbadense, Pima and hirsutum cottons that partially was in accordance with the results obtained herein.

\subsection{Specific combining ability effects}

Estimates of SCA effects of the parental combinations according to factorial mating design for each trait at the two planting dates are presented in Table (4). For FFN, 12 crosses showed negative SCA effects at the two dates; crosses EC1 x PS7, G90 x PS7, EC2 x PS6, and EC2xPS6 at date $D_{1}$, while only G90xPS6 showed significant negative SCA at $\mathrm{D}_{2}$.

Ten out of the 20 crosses at $\mathrm{D}_{1}$ and 12 at $\mathrm{D}_{2}$ exhibited negative SCA effects for DFF, however only the cross G80 x PS6 passed the significance levels at the two dates. Regarding DFB, the crosses G86 x G75, EC2 x PS7 and unexpectedly G80 x G75 showed negative and significant $\mathrm{SCA}$ at the $\mathrm{D}_{1}$ planting date, while only EC2 x G75 and G80 x G75 were significant. Number of fruiting branches per plant showed that crosses G86 x PS7 and EC1xPS7 exhibited significant and positive SCA effects at $D_{1}$, while the crosses G90 x G75, EC2 $x$ PS7 and G80 x PS7 were significant at $\mathrm{D}_{2}$. The cross G90 x G75, represents "high x low" parents significant and positive GCA effects. Regarding plant height, the cross G90 x G83 was significantly shorter especially at $\mathrm{D}_{2}$. Crosses G86 x G75, G90 x PS7, and EC2 x PS6 at $\mathrm{D}_{2}$ were significantly earlier in SCA effects than the other 14 positive SCA crosses with the yield related earliness. None of the ten positive SCA crosses passes the significance level at $\mathrm{D}_{2}$ with this regard. Totally, the five crosses; EC1 x PS7, G90 x PS7, EC2 x PS6, EC2 x G75 and G80xPS7 exhibited the most desirable SCA effects for most traits. Baker and Verhalen (1975) and Hinze et al. (2011) observed relatively high levels of SCA effects for growthbased and yield-based earliness in certain crosses.

\section{Conclusion}

The current study indicated that the studied traits exhibited significant additive and nonadditive variation in their expression, since both GCA and SCA variances were significant. Thus, the appropriate breeding approach for improving tolerance to late planting and to enhance shortening growing season for the current set of Egyptian genotypes would be to isolate the nonadditive genes and simultaneously maintaine the degree of heterogeneity for exploiting the additive component. This can be done practically through backcrossing with the selected genotypes followed by repeated selfing and evaluation for desired performance. On the other hand, cotton breeders more or less consider cotton as a self pollinated crop $(\mathrm{F}=1)$, thus for the traits that showed additive component of greater magnitude than the dominance, the breeder can effectively practice selection at various levels of inbreeding because the additive part of gene action is freely transmissible from a generation to the next.

Perhaps the most important result recorded here was the attempt of shortening growing season to be as short as 150 days compared to the full season genotypes of 180-200 days. If this suggestion coupled with an approximation of first September irrigation termination and minimum yield loss of LP improved cultivars, we would obtain several advantages of LP over full-season production such as reducing seasonal water consumption, reducing insect control pesticides and reducing the populations of boll worms, thrips and other insects by reducing the winter generations, and most importantly attaining great flexibility in cropping pattern that helps in prevail the unavoidable problem of barbadense delaying planting.

Finally, the cotton genotype tolerant to late planting should be shorter than the current cultivated genotypes and low in node number of first branch that is reflected in compacted and earlier flowering pattern, possessed a high 
number of sympodial branches and high yielding capacity reflected in high earliness index. The study tends to recommend the genotypes G90, EC2, PS6 and their $F_{2}$ crosses to start a breeding program aiming to obtain an Egyptian cotton genotype that can be planted around early May.

\section{REFERENCES}

Abdalla A. (2014). Factorial cross analysis of yield and earliness in Gossypium barbadense cottons grown on divergent sowing dates. Egypt. J. Plant Breed., 18(4):607-628.

Abdalla A. (2013). Joint regression and ordination analysis techniques of GXE interaction for the shortening growing season of cotton. Egypt. J. Plant Breed., 17 (6):99-116.

Abdalla A. and Abd- El-Zaher Sh. R. (2012). Promoting- Egyptian cotton sustainability over time, space, and agro-economic variables. Proc. of the $2^{\text {nd }}$ Alexandria International Cotton Conference. Faculty of Agriculture, Saba Basha, Alexandria University, Alexandria, Egypt, April 10 $11,{ }^{\text {th }}$ pp. 35-43

Abdalla A., Abo-El-Zahab A. A. and Radwan S. R. H. (1999). Combining ability for yield and earliness of Pima X Egyptian cotton cultivar crosses. Proc. Belt wide Cotton Conf., Orlando, FL 3-7 Jan. Natl. Cotton Coun.USA

Abdalla A., Atta M. M. and Ameen M. M. (2007). Inter and intra-specific cotton crosses. 1- Heterosis performance and generations' correlation targeted growth, earliness and yield variables of F1 and F2 cotton crosses. Egypt. J. Plant Breed., 11 (2): $813-827$

Abo- El-Zahab A.A. (1994). Integrated-short season production system for Egyptian cotton. Final report. NARP Grant No. 34A-6-8. Natl. Acad. Sci. Tech. Egypt.

Baker R. J. (1978). Issues in diallel analysis. Crop Sci., 18: 533-536.

Baker J. L. and Verhalen L. M. (1975). Heterosis and combining ability for several agronomic and fiber properties among selected lines of upland cotton. Cotton Grew. Rev., 52: 209-223.

Ceccarelli S., Grando S. and Hamblin J. (1992). Relation between barley measured in low-and high-yielding environments. Euphytica, 64:49-58

Chahal G. S. and Singh T. H. (1978).
Application of different mating designs to determine the gene action in Gossypium arboreum L. II. Genetic components of Diallel versus North Carolina approach. Crop Improvement. 5 (1): 21-28.

Clarke J. M., Townley- Smith T. F., Mc-Caig T. N. and Green D.G. (1984). Growth analysis of spring wheat cultivar as varying drought resistance. Crop Sci., 24: 537-541.

Comstock R. E. and Robinson H. F. (1948). The components of genetic variance in populations of biparental progenies and their use in estimating the average degree of dominance. Biometrics, 4: 254-266.

Ehdaie B., Waines J. G. and Hall A. E. (1988). Differential response of land race and improved spring wheat genotypes to stress environments. Crop Sci., 28: 838842.

Esmail H., Mahfouz H. and Edwar M. D. (2005). Mean performance, combining ability and heterosis of new Egyptian cotton genotypes as parental genotypes in breeding program. Egypt. J. Plant Breed. 9 (1):127-145.

Fischer R. A. and Maruer R. (1978). Drought resistance in spring wheat cultivars .IGrain yield response. J. Agric. Res., 29: 897-907.

Godoy A. S. and Palomo G. A. (1999). Genetic analysis of earliness in upland cotton. I. Morphological and phenological variables. Euphytica, 105: 155-160.

Grissco R., Johnson C. and Dumas W. (1984). Experiences in planting cotton in various cover crops. P.85-610.In: Proc. $7^{\text {th }}$ Anni. Southeast No-Tillage System Conf., Alabama. USA.

Hinze L., Campbell B. T. and Russell R. J. (2011). Performance and combining ability in cotton (Gossypium hirsutum L.) populations with diverse parents. Euphytica, 181: 115-125.

IRRESTAT for windows (2005). A computer program for data management and statistical analysis of experimental data. Version 5, Biometrics and Bioinformatics Unit, IRRI.

Khanna R. and Viswana C. (1999). Evaluation of heat stress tolerance in irrigated environment of $T$. aestivum and related species. I-Stability in yield and yield components. Euphytica, 106: 169-180.

Keim K. R., Quisenberry J. F. and Ray G. A. 
(1985). Heritability of leaf characteristics in upland cotton. Crop Sci., 30:644-649.

Kittock D. L. and Taylor B.B. (1985). Summary of 25 years of cotton date of planting tests in Arizona. P. 31-33. Univ. of Arizona, Agric. Cotton Rep. Ser. Tucson, AZ. USA.

Lin C. H. , Zang X. W. and Huang Y. G. (1990). Study on the techniques for high yield of short season cotton in Chuang-Huai high plains. China Cottons, 6:22-23.

May O. L. and Bridges Jr. B. C. (1995). Breeding cottons for conventional and late -planted production systems. Crop Sci., 35: 132-136.

Nelson R. L. and Bernard R. L. (1984). Production and performance of hybrid soybeans. Crop Sci., 24:549-553.

Percy R. and Turcotte E. L. (1988). Development of short and coarse- fibered Pima cotton for use as parents of interspecific hybrids. Crop Sci., 28: 913-916.

Pettigrew W. T. and Meredith W. R., Jr. (2009). Seed Quality and Planting Date Effects on
Cotton Lint Yield, Yield Components, and Fiber Quality. J. Cotton Sci., 13:37-44.

Porter P. M., Sullivan M. J. and Harvy L. H. (1995). Cotton variety by planting date interaction in southeast. Proc. Belt Cotton Conf., 3-7 Jan. TN. USA. pp 516-521.

Silvertooth J. C. (1994). Cultural and management practices for Pima cotton production. Proc. Belt. Cotton. San Diego. USA, pp 87-89.

Smith, C.W. and Varvil S. A. (1984). Differential recovery among cotton genotypes following early season defoliation. Crop Sci., 24: 150-153.

Tang B. J. N. , Jenkins J. C., McCarty Jr., Watson C. E. and Creech R. G. (1996). Evaluation of genetic variances, heretabilities, and correlations for yield and fiber traits among cotton F2 hybrid populations. Euphytica, 91:315-322.

Van Oosterom E. J., Kleijn D. and Ceccarelli S. (1993). Genotype - by - environment interactions of barley in the Mediterranean region. Crop Sci., 33:669-674.

\title{
إمكانية تربية أقطان الباربادينس قصيرة الموسم عن طريق الزراعة المتأخرة
}

\author{
عبدالله محمد على عبدالله \\ قسم المحاصيل - كليةالزر اعة - جامعة القاهرة ـ الجيزة ـ مصر
}

\begin{abstract}
ملخص
هدفت الدراسة الحالية الي اجراء تحليل ور اثي سريع لاختبار طرز من اقطان الباربادينس لتحمل التأخير في ميعاد

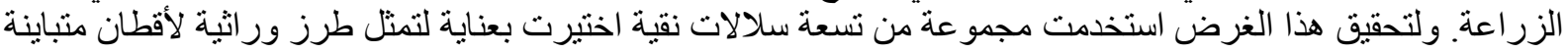

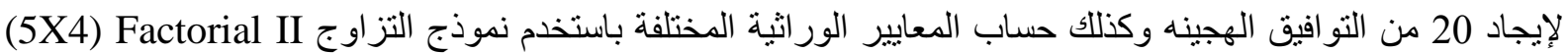

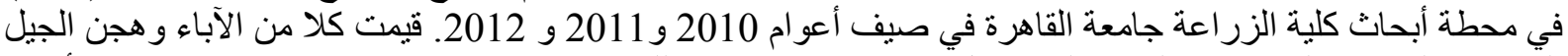

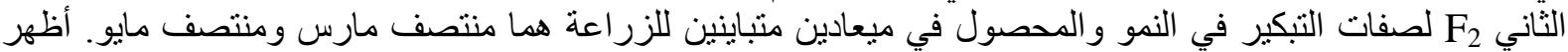



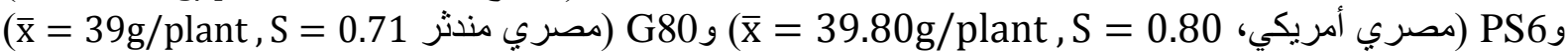
و الهجن G86x G75, G90x G75, G80 x PS7, and G80 x G83 بقدرات محصولية عالية في الزراعة المتأخرة EC1xPS6, G90xPS7, وكذللك قدرات عالية ومتوسطة علي تحمل التأخير في ميعاد الزراعة. كما تميزت الهن واول EC2xPS6, EC2xG83 and G80xPS6

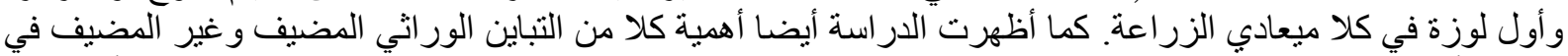

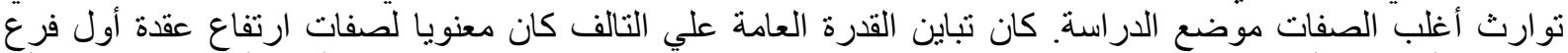



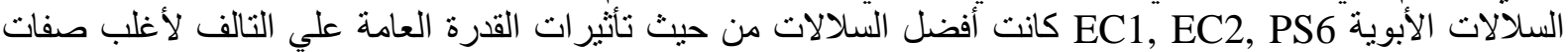

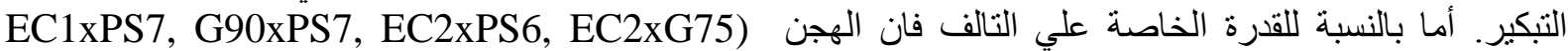
(G80xPS7

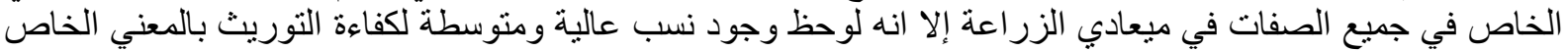

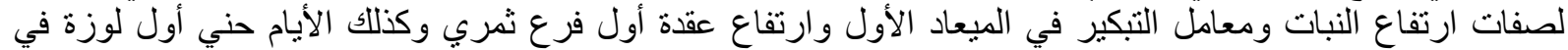

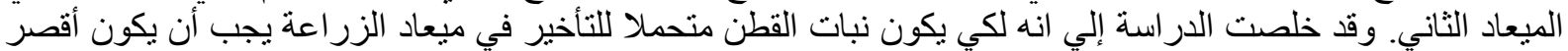


طولا من الطرز الحالية ومنخفض في عقدة الفرع الثمري الأولي أي منضغط في منطقة النز هير ومبكر في التلويز



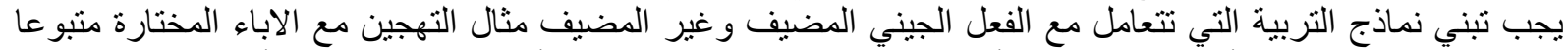

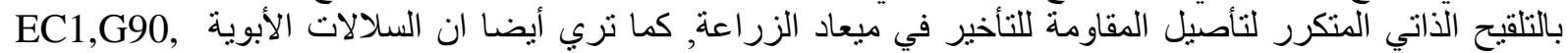
EC2, وكذلك الهجن EC1 x PS6, G90 x PS7, EC2 x PS6, EC2 x G83 بمكن استخدامها في استحداث بر امج تربية لإنتاج طر از ور اثلي من أقطان الباربادينس بمكن زر اعته حو الى ألى أول مايو.



